\title{
Sublingual Artery
}

National Cancer Institute

\section{Source}

National Cancer Institute. Sublingual Artery. NCI Thesaurus. Code C53002.

An artery arising from the lingual artery that supplies the sublingual gland and

surrounding muscles as well as the mucous membranes of the mouth and gums. 